\title{
On the prosodic realization of Spanish ¿no?-tags from a pragmatic perspective
}

\author{
Anna Gazdik \\ University of Graz \\ anna.gazdik@uni-graz.at
}

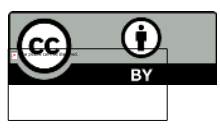

Received: $15-03-21$

Accepted: 30-09-21

Published: 22-02-22

How to cite: Anna Gazdik. 2022. On the prosodic realization of Spanish ¿no?-tags from a pragmatic perspective. RLLT17, eds. Ora Matushansky, Laurent Roussarie, Michela Russo, Elena Soare \& Sophie Wauquier. Special issue of Isogloss Open Journal of Romance Linguistics 8(2)/16, 1-19.

DOI: https://doi.org/10.5565/rev/isogloss.134

\begin{abstract}
The aim of this paper is to report on an empirical study investigating the prosodic realization of the Spanish tag ino? added to host clauses with different clause types, realizing various speech act types. Although ¿no? is commonly assumed to display a rising contour, we show that there are level and falling contours over the tag as well, even though rising contours are indeed dominant. The observed tendencies confirm the hypotheses that the contour over the tag is influenced both by the clause type of the host clause ( $₫$ no? in exclamatives and interrogatives display wider tonal excursions, and is more often realized with a rising contour than imperatives and declaratives). On the other hand, the type of the modified speech act also plays a role: commissives show more rising contours than expressives, directives and assertives. On the pragmatic side, we assume (with Kiss (2018)) that the function of the tag is the attribution of the whole discourse move to the addressee. In addition, we suppose that the rising contour over the tag signals a call on the addressee to interpret the whole discourse move as a meta-question on the attribution of the realized speech act to the addressee.
\end{abstract}

Keywords: tag questions, ¿no?, speech acts, clause types, intonation, attribution, call on addressee 


\section{Introduction}

The Spanish negative adverb ¿no? used as a question tag (1) is commonly assumed to turn every statement into a question (cf. Osa 2017) with a meaning paraphrasable as 'right?', 'don't you think?', 'isn't it like that?' (cf. García Vizcaíno 2005). From a pragmatic perspective, the speaker expresses that she seeks confirmation of the truth of the propositional content asserted in the host clause, whereby ino? helps to avoid confrontation with the addressee (cf. García Vizcaíno 2005, Butt and Benjamin 2013).

(1) Declarative clause - assertion (subjective statement) participar en un congreso/y presentar un trabajo//creo que es bastante interesante/no?

'To take part in a congress and present a paper, I think it is quite interesting, isn't it?' (C-ORAL-ROM, [efamdl42] (Cresti and Moneglia 2005))

However, the distribution of $¿$ no? is not restricted to declarative clauses conveying assertions (see section 2 below). The host clause can be of every major clause type; furthermore, it can convey a wider range of speech acts than assertions.

Concerning their prosodic realization, Spanish tags has not yet been described to the same extent as their English counterparts (see, for instance, Dehé and Braun 2013). Estebas-Vilaplana and Prieto (2010) mention them when discussing confirmation questions, and illustrate them with one example including the tag $\measuredangle e h ?$, exhibiting a rising contour (L* H\% in the Spanish ToBI notation system (cf. Prieto and Roseano 2010)). Similarly, the tag ¿no? is also assumed to be realized with a rising contour without empirical underpinnings (cf. Ortega Olivares 1985, García Vízcaíno 2005). At the same time, as observed by Escandell-Vidal (1999, 2017, etc.) on various occasions, questions that involve attribution of their content to the addressee are usually realized with a risefall circumflex contour (exhibiting a rise until the nuclear pitch accent, which is followed by a fall to a lower level than the preceding low tones in the sentence (corresponding to $\mathrm{L}+{ }_{i} \mathrm{H}^{*} \mathrm{~L} \%$ in the Spanish ToBI notation). Since $i n o$ ? arguably involves attribution (see section 3 below), the question arises whether ¿no? follows the rising or the circumflex pattern, taking into consideration its distribution across clause and speech act types. The aim of the present empirical study is, thus, to investigate the possible prosodic realizations of $;$ no?-tags in Extremaduran Spanish, in the light of the pragmatic restrictions on its use.

\section{The distribution of ¿no?}

Now we consider the distribution of ¿no? according to the clause type of the host clause it is added to, and the speech act it conveys. (1) above and (2) illustrate declarative clauses conveying assertions: (1) a subjective statement, whereas (2) a factual statement. In (3), all clauses are imperative, conveying a directive (3a), a (3b) cohortative, and a (3c) 'displaced' directive speech act. In the latter, the order is not directed to the addressee, but to a third person. In (4), the interrogative clause conveys a rhetorical question, whereas in (5) an expressive act is realized with the help of an exclamative clause. 
(2) Declarative clause - assertion (factual statement)

CRI: tus padres estaban / en casa / no?

'your parents were at home, weren't they?'

(C-ORAL-ROM [efamd108], Cresti and Moneglia (2005))

(3) Imperative clauses

a. Directive (weak imperative)

vale // no te corre prisa / ¿no?

'all right, don't rush, ok?' (C-ORAL-ROM [etelef02])

b. Cohortative

Venga, vamos a otro sitio, ¿no?

'Come on, let's go somewhere else, right?' (Osa, 2017, p. 98, 4)

c. 'Displaced' directive

Que salgan de aquí, ¿no?

'They should get out of here, ok?' (García Vizcaíno, p. 9, 31)

(4) Interrogative clause - rhetorical question

¿De qué está hablando, no?

'What is he talking about, right?' (ibid.)

(5) Exclamative clause - expressive

Qué tontería, ¿no? no entiendo esa discusión

'What a stupid thing! I don't unserstand this discussion.'

(C-ORAL-ROM, [efamdl16])

On the other hand, other speech acts, like genuine questions (6), strong imperatives (7), declarations (8), certain expressives (9) and generally performatives (10) cannot host ¿no?:

(6) Genuine question

¿Cómo te llamas?, \# ¿no?

'What's your name, \#right?'

(7) Imperative clause - strong imperative

¡Ven aquí!, \#¿no?

'Come here, \#right?'

(8) Declarative clause - declaration

Os declaro marido y mujer, \# $;$ no?

'I declare you husband and wife, \#right?'

(9) Expressive

Muchas gracias, \# ¿no?

'Thanks a lot, \#right?'

(10) Declarative clause - commissive (performative)

Te lo prometo, $\#_{i}$ no? 
'I promise it to you, \#right?'

This distribution has arguably pragmatic reasons, to which we turn in the next section.

\section{Pragmatic considerations}

The approach adopted in the present paper is based on three analyses: a general one of clause types and speech acts (cf. Beyssade and Marandin, 2006), and two focusing on ¿no? (cf. Kiss, 2018; Osa, 2017).

\subsection{Tag questions as hybrid discourse moves}

Beyssade and Marandin (2006) propose a comprehensive framework to account for the correspondences between clause types and the speech acts they may realize when uttered. In the formalization of their proposal, they rely heavily on Ginzburg (1996) and Ginzburg and Sag (2000). As the authors argue, each major clause type (declarative, interrogative, imperative, exclamative) is associated with a basic semantic meaning or content, for which Ginzburg and Sag (2000) propose a rich ontology. Furthermore, clause types are typically associated with a type of speech act or illocutionary force. This is illustrated in Table 1.

Table 1. Semantic content types according to Ginzburg and Sag (2000) and the typical speech acts conveyed

\begin{tabular}{|l|l|l|}
\hline Clause type & Semantic content type & $\begin{array}{l}\text { Typical speech act } \\
\text { conveyed }\end{array}$ \\
\hline declarative & proposition (p) & assertion \\
\hline interrogative & question (q) (propositional abstract) & question (directive) \\
\hline imperative & outcome (o) & directive \\
\hline exclamative & fact (f) & exclamation \\
\hline
\end{tabular}

Source: based on Beyssade and Marandin (2006)

However, as is well-known, an utterance can convey speech acts other than the typical one conveyed by its clause type. Beyssade and Marandin (2006) make this explicit by disentangling two facets of illocutionary acts: speaker commitment and call on the addressee. When performing an utterance, a speaker signals his or her commitment to the semantic content of the utterance (to a proposition, to an issue, to the actualization of a future situation, or to a fact), based on the clause type. When the move is simple, the speaker at the same time calls on the addressee to make the same commitment (for instance, to take up the assertion conveyed by a declarative clause, the propositional abstract conveyed by an interrogative clause, or the directive conveyed by an imperative clause and commit to its semantic content). On the other hand, if the move is hybrid, the call on the addressee differs from the speaker commitment. Hybrid moves are indicated to the addressee explicitly, by formal means, among them by particles, tags and intonation. For instance, in the case of the French tag n'est-ce pas? 'isn't it like that', the speaker can call on the addressee to take up the assertion conveyed by the utterance as a question, which results in a confirmation-seeking question: 
(11) French

Marie est arrive'e, n'est-ce pas?

'Marie has arrived, hasn't she?' (ibid., p. 56, 34)

This approach formalizes the above-mentioned layman observation (' $i n o$ ? turns every statement into a question') correctly. Moreover, due to the rich semantic ontology used, the fact that ino? can modify speech acts other than assertions can be accommodated as well. However, its contribution to the discourse has other facets as well, namely tentativity and attribution, which are not made explicit in Beyssade and Marandin (ibid.)'s framework. These are introduced in sections (3.2) and (3.3), respectively.

\section{2. ¿No?-tags creating tentative speech acts}

Apart from turning an assertion (or a directive, an exclamative, or a rhetorical question) into a question, with the use of ¿no? the speaker in a way mitigates or postpones his or her commitment to the given speech act. Osa (2017) formulates and formalizes this by claiming that by adding ino? to a speech act, the speaker makes the whole discourse move tentative, i.e. to which he or she cannot commit to immediately, only after the addressee has accepted it. The author formalizes her analysis in a dynamic framework, building her analysis on the combination of two approaches, that of Beyssade and Marandin (2006) and Malamud and Stephenson (2015). Malamud and Stephenson (ibid.) adopt the discourse model proposed by Farkas and Bruce (2010), but complete it by projected sets for each discourse participant's commitments that host preliminary or tentative commitments. This approach can account for the use of $i n o$ ? in assertions. If the speaker utters an assertion modified by ¿no?, he or she will not immediately be committed to it, but it will be added to his or her projected commitment set. If the addressee accepts it (confirms its truth), $p$ will be added to the speaker's commitments and to the Common Ground (the set of mutually accepted propositions (cf. Stalnaker, 1978)) as well. However, it is not clear what happens to speech acts other than assertions that do not denote propositions. To solve this problem, Osa (2017) adopts the ontology of semantic content types already introduced in Table (1). Using this system, Osa (2017) claims that outcomes, questions and facts can also be placed in projected sets, and this is exactly the effect of $¿ n o$ ?

\section{3. ¿No?-tags marking speech act attribution}

Kiss (2018) does not agree with Osa's analysis, mainly for two reasons. The first problem is the tentativity-approach. Speech acts can be made explicitly tentative with the paraphrase de 'jame + verb 'let me ...'. However, some speech acts that are paraphrasable with de'jame cannot host ¿no?, which means that tentativity alone cannot explain the behaviour of ¿no?. Compare:

(12) a. Déjame preguntarte cuántos años tienes.

'Allow me to ask you how old you are.'

b. ¿Cuántos años tienes, \#no? (ibid., p. 3, 5a-b)

(13) a. Déjame prometerte una cosa.

'Let me promise you one thing.'

b. Te prometo una cosa, \#¿no? (ibid., p. 3, 5c-d) 
Secondly, Osa (2017)'s analysis does not account for the difference with respect to ¿no? observed in imperatives. As García Vizcaíno (2005) also observes, commands (directive speech acts) cannot uniformly host ino?: cohortatives (3b) and weak imperatives (3a) are grammatical, when modified by $i n o$ ?, whereas strong imperatives (7) are ungrammatical. Kiss (2018) proposes to explain the tentative 'feel' of utterances hosting ¿no? differently and claims that by adding ¿no? to an utterance, the speaker attributes the whole illocutionary act conveyed by the utterance to the addressee, accompanied by a call on the addressee to confirm commitment to the content of the speech act. In other words, when adding ino? to an utterance, the speaker checks if the addressee would perform the same illocutionary act, (a possible paraphrase would thus be "I say F(p) and you would say F(p) too, wouldn't you?" (ibid.)). This also accounts for the politeness effect of $¿ n o$ ?: the addressee is in a position where he can refuse to accept the attributed illocutionary act.

As Kiss (2018) argues, the attribution approach explains why ¿no? can be added to some speech acts, but not to others. Roughly, "an illocutionary act is attributable if the change it proposes in the mutual commitments is no different from the case of a 'simple', i.e. non-attributed illocutionary act." (ibid., p. 9). Assertions are readily attributable along with rhetorical questions that supposedly also have assertive illocutionary force (cf. Asher and Reese, 2007) and exclamatives that are also based on an assertion and express the speaker's attitude to it. The reason why cohortatives and weak imperatives (suggestions and warnings) are attributable is that they function as polite reminders of a rule or state of affairs that is already known to the addressee and complying with it is beneficial for him or her, i.e. the addressee could or should have come to the same conclusion himself/herself. The other type of directives (strong commands) are different: they are imposed upon the addressee by the (authoritative) speaker, and the addressee is expected to comply with it because of the authoritative position and not because he would come to the same conclusion himself (see Portner 2018 about the weak/strong imperative distinction). Genuine questions behave like strong commands: they function as a request to provide an answer. Similarly, expressives (9) also constitute bad candidates for attribution. The reader is referred to Kiss (2018) for more details of the analysis.

\subsection{The approach adopted in this paper}

The pragmatic approach we work with in the present paper contains elements of both Beyssade and Marandin (2006)'s and Kiss (2018)'s analysis. Following Kiss (ibid.), we assume that $i n o$ ? involves the attribution of speech acts to the addressee. Furthermore, like Beyssade and Marandin (2006), we also assume a discourse component call on the addressee, which is, in the case of $¿ n o$ ? a question operating on the attributed speech act. It expects confirmation of the attribution (i.e. that the addressee accepts the attribution, in other words, he or she admits commitment to the same semantic content). The aim of this paper is to examine which parts of these pragmatic meanings are transmitted via prosody. We now turn to the presentation of the prosodic experiment.

\section{Research questions and hypotheses}

The following research questions (RQ) and hypotheses are put forward:

RQ A) The influence of the clause type: The question is whether the intonation of the host 
clause, more precisely the contour over the nuclear configuration preceding the tag influences the contour over the tag.

As is well known, prosody contributes to distinguishing between the different sentence modalities in Spanish (cf. Escandell-Vidal and Prieto, 2020). In Central Castilian Spanish, the clearest contrast is between declarative sentences, produced with a falling contour $\left((\mathrm{H}+) \mathrm{L}^{*} \mathrm{~L} \%\right)$, whereas polar interrogatives show a rising pattern $\left(\mathrm{L}^{*} \mathrm{H} \%\right.$ or $\mathrm{L}+\mathrm{H} \% \mathrm{H} \%$ ). Exclamations are, however, not associated with a contrastive contour, but follow the declarative pattern and are characterized by expanded pitch range, increased intensity and duration of some segments. When it comes to imperatives, since verbal morphology is a clear indicator of this modality, they do not exhibit a specific intonational contour either. They also follow the declarative pattern, although higher F0 toplines and wider tonal excursions indicate a higher speaker involvement, and higher intensities can correlate with higher social position of the speaker relative to the hearer.

Hypothesis 1: We thus expect to find more level or falling contours over ¿no?-tags added to declarative host clauses than in the case of interrogatives (rhetorical questions).

Hypothesis 2: We expect expanded pitch range in exclamations, and wider tonal excursions in imperatives as well.

RQ B) The influence of the speech act: The question is whether some inherent properties of the different speech acts influence their relative attributability, i.e. if some speech acts are more easily attributable than others and whether intonation could reflect the speaker's confidence in the success of the attribution.

It is a long-standing observation that intonation contours, similarly to discourse markers and modals, can convey (degrees of) epistemic commitment (see Prieto and Roseano (2021) and the references therein): for instance, in assertions, the falling final tune is often assumed to be an indicator of high speaker confidence (with respect to the truth of the proposition expressed), whereas sentence-final high or mid-level boundary tones signal reduced speaker commitment or the lack of it (see, for instance, Asher and Reese (2007), Farkas and Roelofsen (2017), and Portes et al. (2014)). Since ¿no? conveys the attribution of the speech act to the addressee, one might suppose that the speaker can be more or less certain in the attributability of a given speech act. It is expected that assertions and speech acts with an assertive core (rhetorical questions, exclamatives) are more easily attributable than commissives and directives. In prosodic terms, high boundary tones are associated with openness, incompleteness, doubt or uncertainty, whereas low ones with finality (Pierrehumbert and Hirschberg, 1990; Ladd, 2008, p. 6; Büring, 2016, p. 229).

Hypothesis 3: It is thus expected that commissives and directives are associated with more rising tones in the realization of the tag than assertives, rhetorical questions and exclamatives.

RQ C) Division of labour between intonation and the tag: the question is whether the pragmatic contribution of the tag itself can be disentangled from that of its prosodic realization, and if so, how.

For instance, concerning English tags, Farkas and Roelofsen (2017) argue that rising contours on the tag in English indicate the speaker's low, whereas falling contours his or her high credence level of commitment to the propositional content of the base 
clause. As we have seen, ¿no? makes two crucial pragmatic contributions: attribution of the speech act to the addressee and a call on the addressee to interpret the discourse move as a (confirmation) question.

Hypothesis 4: We expect that the contour over the tag may convey one of those components.

\section{The empirical study}

\subsection{Methods and materials}

The participants The prosodic experiment was conducted in March 2019, in Cáceres, Extremadura, Spain. 21 speakers (19 female, 2 male) took part in the recording. They all grew up in Extremadura (Cáceres, Badajoz, Mérida and the surrounding villages), and are native speakers of the local dialect (Extremaduran). They were all students enrolled in post-secondary education (1st year and masters' students) at the University of Cáceres, which means that all of them had some foreign language skills. The choice of this location was motivated by two factors. Firstly, Extremaduran still counts as an underrepresented variety in the prosodic literature. Secondly, since the local university is almost exclusively attended by students coming from the region, the participants were expected to constitute a dialectally homogenous group, which would not have been the case in a more international city.

The recordings The recordings were made with a H5 Zoom Handy recorder. Due to the specificity of the data to be elucidated, a semi-spontaneous way of production was chosen. The participants were instructed to act out 12 mini-dialogues in pairs in the most natural way possible. They changed the roles of speaker A and B after the first round. These are illustrated by 4 examples in (14)-(17):

(14) Visitas con tu hermano a la familia de unos amigos y al iros le comentas lo grande que está su hijo:
A: ¡Cómo ha crecido! ¿no?
B: Está enorme.

(15) Estás observando a tu nuera preparando la ropa para lavar y le dices:

A: ¡Oye! No pongas la ropa blanca y negra juntas, ¿no?

B: Gracias, pero no me hacen falta consejos.

(16) Tu amigo está desesperado porque su relación va mal y te pide consejo. Le dices

A: Pues habla con ella, ¿no?

B: Ya, pero no quiere escucharme.

(17) Un amigo te pregunta si puedes ayudarle a editar una página web. Miras la página y le preguntas a tu amigo:

A: Es como el HTML, ¿no?

B: No exactamente... tiene otro nombre que no recuerdo, pero funciona casi igual. 


\subsection{Background on Extremaduran intonation}

Before proceeding to the evaluation of the data, a short introduction on Extremaduran intonation is due, even more so, because it displays important differences in comparison to Central Castilian Spanish. According to Elordieta, Masa, and Romera (2020), Extremaduran Spanish is one of the most underexplored varieties, when it comes to intonation. In their study, they analyzed the intonation of declaratives and of polar and constituent interrogatives, in total 232 sentences, in guided conversations.

Generally, the authors observed a greater variety of nuclear contours in Extremaduran than in Central Castilian Spanish (Estebas-Vilaplana and Prieto, 2010). In polar questions, the predominant nuclear contour (43\%) was falling $\mathrm{H}^{*} ! \mathrm{H} \%, \mathrm{H}^{*} \mathrm{~L} \%$, $\mathrm{H}+\mathrm{L}^{*} \mathrm{~L} \%, \mathrm{H}^{*}+\mathrm{L} \mathrm{L} \%$, unlike in Central Castilian Spanish, where rising contours are dominant $\left(\mathrm{L}^{*} \mathrm{H} \%\right)$, but they also identified circumflex $(22 \%)\left(\mathrm{L}+\mathrm{H}^{*} ! \mathrm{H} \%, \mathrm{~L}+\mathrm{H}^{*} \mathrm{~L} \%\right)$, low $(18 \%)$ ( $\left.\mathrm{L}^{*} \mathrm{~L} \%\right)$, and rising (17\%) contours ( $\mathrm{L}^{*} \mathrm{H} \%, \mathrm{~L}+\mathrm{H} \%, \mathrm{H}^{*} \mathrm{LH} \%, \mathrm{~L} *$ !H\%). The dominance of falling contours in polar interrogatives, which clearly realized information-seeking questions, is a striking result. The presence of circumflex contours in neutral, information-seeking questions is noteworthy as well, since it contradicts, for instance, Escandell-Vidal (1999), who analyzed it as an indication of repetition or attribution. Note that the results presented in Elordieta, Masa, and Romera (2020) are explicitly phonetic. A phonological analysis is postponed for future work.

\subsection{Descriptive results}

The aim of the present section is to introduce the results of the study on a descriptive level. The analysis of the data follows in section 5.4. The recordings were analyzed using Praat (Boersma and Weenink 2010). The sound files were edited into individual files, and annotated mostly manually, though parts of the labelling were executed with the help of a Praat script. In the present paper, we concentrate on the contour over the tag. ${ }^{1}$

The patterns identified During the evaluation of the data, the following contour types were identified: level (Figure 1) ${ }^{2}$, different degrees of rising (Figure 2 illustrates sharp, whereas Figure 3 light rising contours), and falling (Figure 4). These contour types were distinguished with the help of an analysis of the f0 minima and maxima values within the domain of the tag in terms of semitones.

\footnotetext{
1 Although there are other important aspects to examine, like the duration or the prosodic integration of the tag into the host clause, these are beyond the scope of the present paper.

2 Note that throughout the Praat annotations, the Spanish SAMPA (Speech Assessment Methods Phonetic Alphabet) is used. For instance, 'T' stands for the voiceless, labiodental fricative. The numbers $63 / 6$ read as speaker/situation. The 21 speakers were randomly assigned a number between 42 and 67, and the situations between 1 and 30 .
} 
Figure 1. ¿Comparado con el resto de la Península es muy impresionante, ¿no? realized with a level contour over the tag

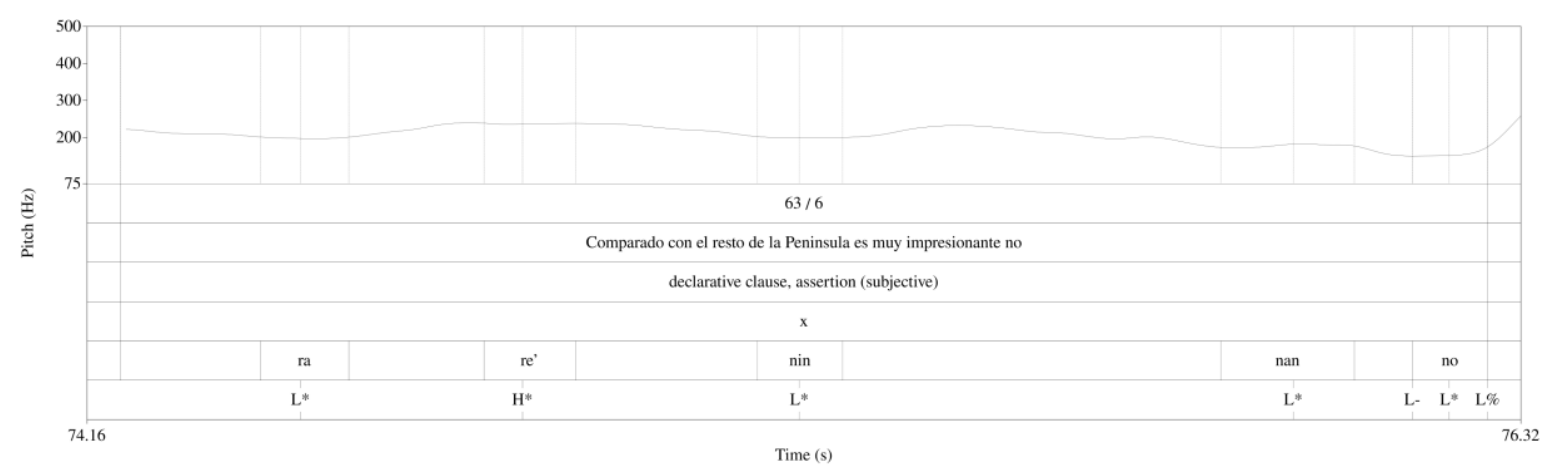

Figure 2. ¡Cómo ha crecido!, ¿no? pronounced with a sharp rising contour over the tag

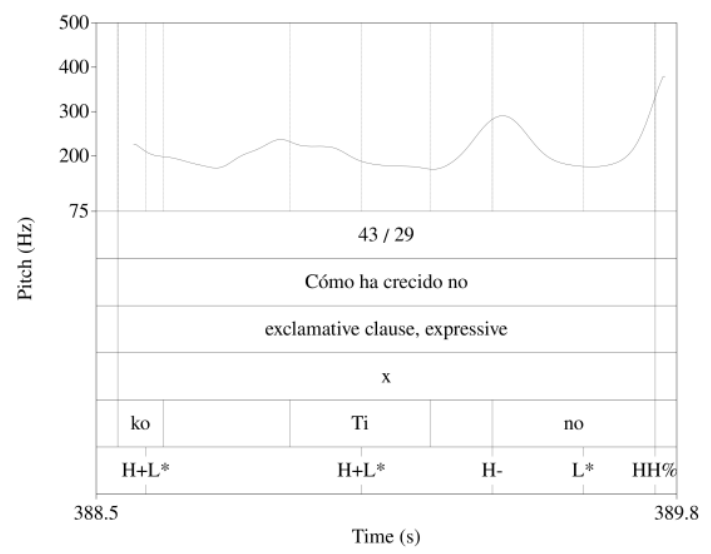

Figure 3. ¿Pero quién se comprará este libro, no? realized with a light rising contour over the tag

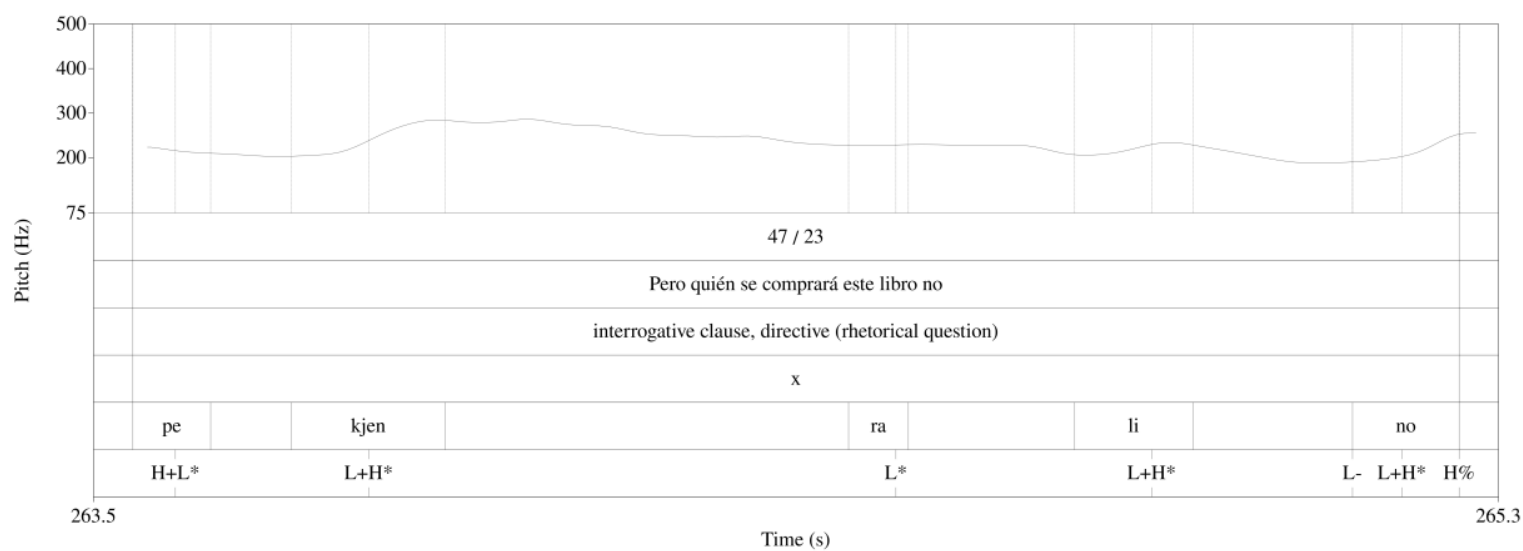


Figure 4. Ponte el vestido nuevo para la fiesta, ¿no? realized with a falling contour over the tag

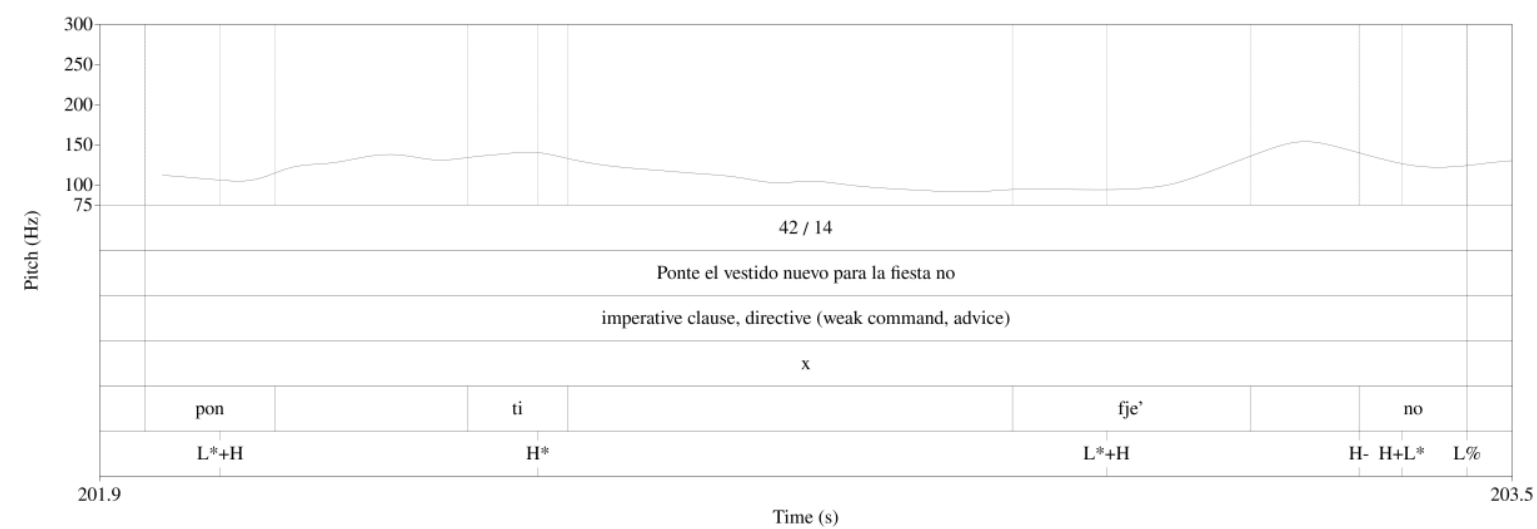

Remarks on labelling We choose to analyze the tag as a separate intermediate phrase (ip), comprising a pitch accent, and ending in an ip and an IP boundary tone. The general problem is that these tonal events are difficult to tease apart in a monosyllabic tag, such as ¿no? (see Table 2).

Table 2. Tonal configuration over the end of the host and the tag

\begin{tabular}{|c|c|c|c|c|}
\hline \multicolumn{2}{|c|}{$\begin{array}{l}\text { Tonal configuration at the end of } \\
\text { the host clause }\end{array}$} & \multicolumn{3}{|c|}{ Domain of the tag } \\
\hline pitch accent & boundary tone & pitch accent & ip boundary & IP boundary \\
\hline $\mathbf{T} *_{1}$ & $\mathrm{~T}-1$ & $\mathrm{~T}_{2}$ & $(\mathrm{~T}-2)$ & $\mathrm{T} \%$ \\
\hline
\end{tabular}

Concerning the labelling, we concentrated on three tonal events: the ip boundary tone preceding the tag $\left(\mathrm{T}_{-1}\right)$, the pitch accent over the tag $\left(\mathrm{T}^{*}\right)$ and the final IP boundary tone (T\%), supposing that it falls together with the ip boundary tone at the end of the tag $\left(\mathrm{T}_{-2}\right)$. The labels used are summarized in Table 3.

Table 3. Contour types and subtypes with the corresponding ToBI labels reflecting a phonetic and a phonological approach

\begin{tabular}{|l|l|l|l|}
\hline Contour & Subtypes & \multicolumn{2}{|l|}{ ToBI labels } \\
phonetic \\
Level
\end{tabular}

A few remarks are due here concerning the ToBI labels used:

- The labels in the textgrids intend to reflect a broad phonetic transcription, i.e. neither do they correspond to absolute frequency values of the $f 0$, nor do they reflect a phonological analysis. 
- Rising contours can display two configurations: a continuous rise from a L- ip boundary tone $\left(\mathrm{L}+\mathrm{H}^{*} \mathrm{H} \%\right)$, or a fall-rise pattern $\left(\mathrm{L}^{*} \mathrm{H} \%\right)$, in case the ip boundary tone preceding the tag is H-. In this latter case, the tag starts with a fall in order to make it possible to end in a rise. From a phonological perspective, these types can be summed up under the same abstract rising tonal configuration $/ \mathrm{L}^{*} \mathrm{H} \% /$, see Table 3 .

- Although Estebas Vilaplana (2009) assumes four contrastive levels of boundary tones in Spanish, in the present study two suffice for representational purposes (light rise $\mathrm{H} \%$ and sharp rise $\mathrm{HH} \%$ ). However, in the analysis, both are considered as instances of the same category rise.

Distribution Figure 5 depicts the distribution of the above contour types. Although the rising contour clearly dominates $(70.6 \%)$, one cannot ignore falling $(8,7 \%)$ and level $(20,6 \%)$ contours either. Looking at the variation according to speakers (Figure 6), it is also clear that the contours do not distribute evenly among the speakers: although most of them pronounce the tag in most cases with a rising contour (and speakers 43, 44, 45, and 65 use exclusively rising contours), falling contours dominate by speaker 42 , and level contours by speaker 49,62 and 67. This suggests idiolectal variation among the speakers.

Figure 5. The distribution of contour types over ¿no?-tags

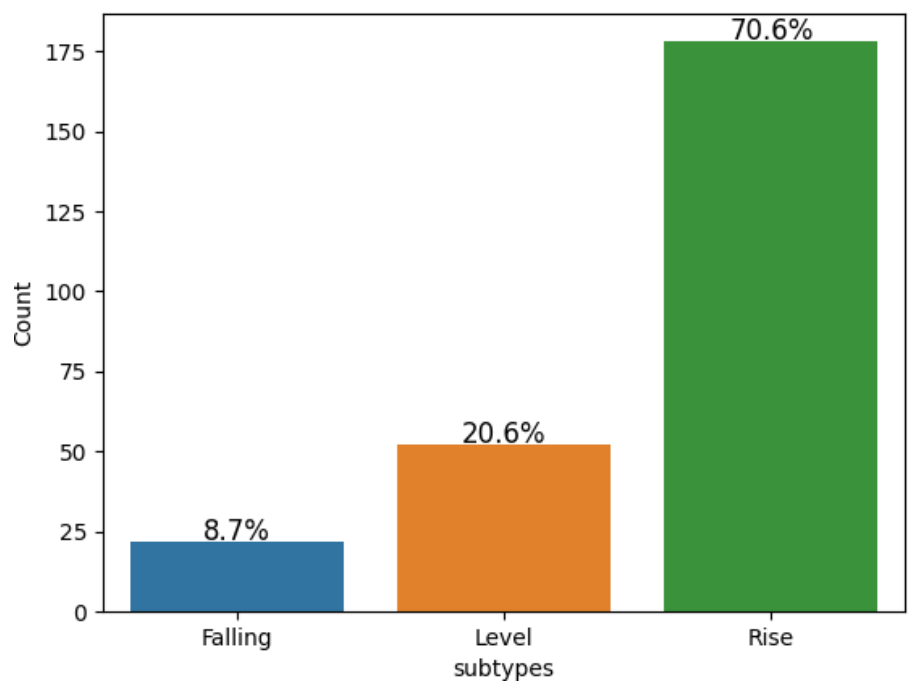


Figure 6. Variation of contour types according to speakers

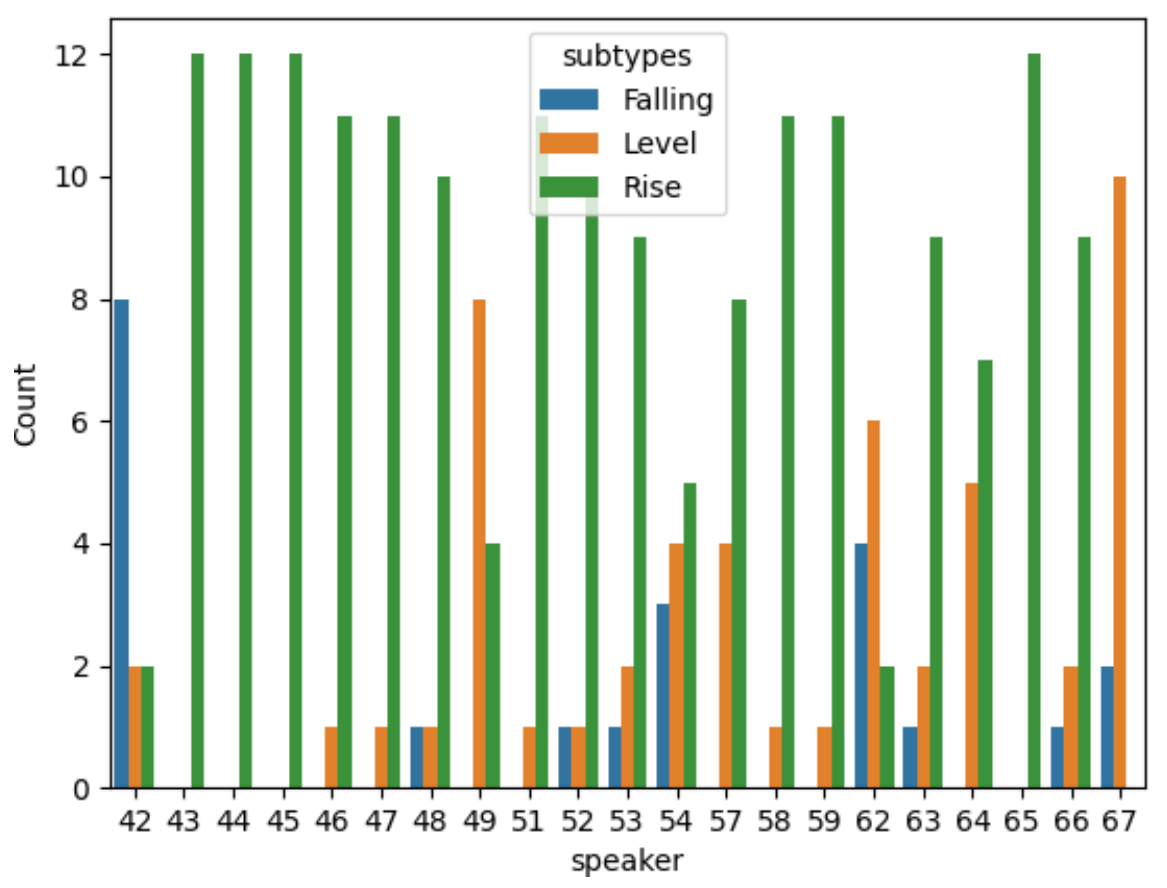

Turning now to the questions raised in section 4 , first the possible connection between speech act types and the contour over the tag has been investigated. This is plotted in Figure 7 for all the 12 recorded items, according to speech act type and clause type. ${ }^{3}$ Although the differences are subtle, tendencies can be observed: commissives and expressives receive almost exclusively rising contours, followed by directives, and finally assertives. From another perspective, assertives receive the most level contours, followed by directives, and finally by expressives and commissives. The assertive speech acts conveying a factual statement and a rhetorical question are rather exceptional, since they pattern with expressives. Figure 8 indicates the pitch span of the tag in the 12 items according to speech act types and clause types. One can see the same subtle differences when looking at the mean value: commissives and expressives, together with the factual statement and the rhetorical question involve a larger pitch span than the most directives and assertives. In the next section, we attempt to account for these observations.

\footnotetext{
3 The abbreviations used in Figures 7 and 8 are as follows: adv=advice, ass=assertive, com=commissive, decl=declarative, dir=directive, excl=exclamative, expr=expressive, fact=factual statement, $i m p=$ imperative, int=interrogative, rhetq=rhetorical question, subj=subjective statement, war=warning. The number in brackets refers to the recorded item.
} 
Figure 7. Contour types according to speech act types

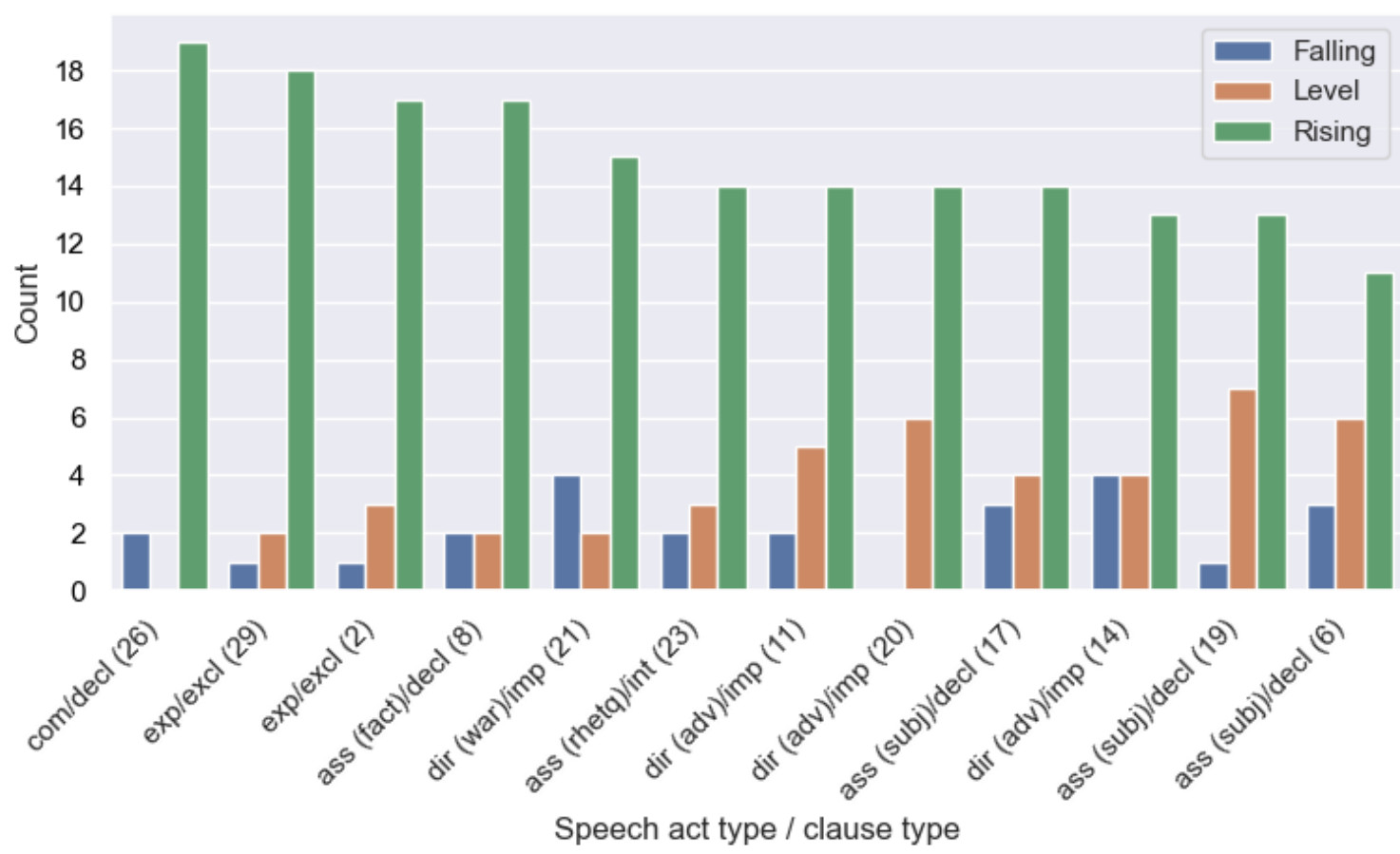

Figure 8. The pitch span of the tag in semitones according to clause type and speech act type

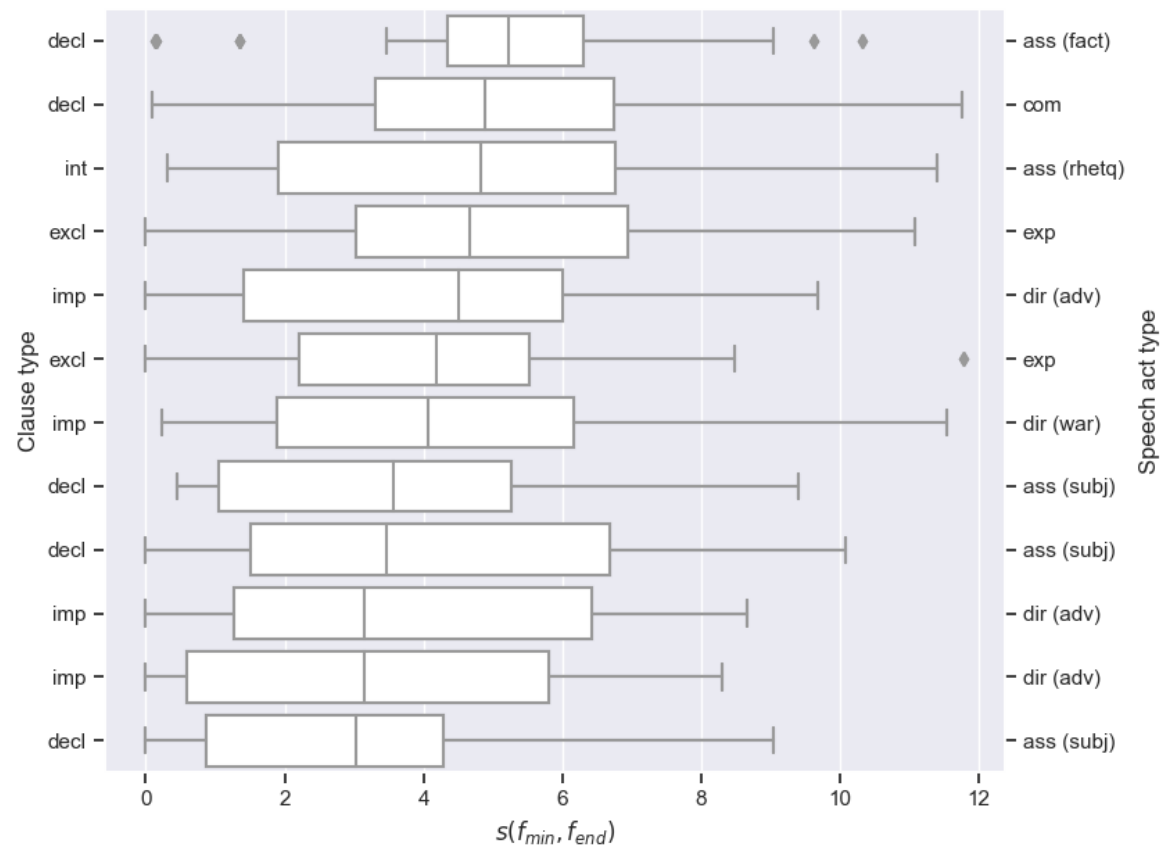

\subsection{Discussion and analysis}

Generally it can thus be observed that the dominance of rising final contours in utterances comprising a ¿no?-tag at first sight contradicts Elordieta, Masa, and Romera (2020)'s 
observations, in that the authors found mostly falling and circumflex contours in polar questions. However, ¿no?-tags realize non-canonical, biased questions, that, in addition to the pragmatic differences, are expected to display intonational differences compared to neutral, information-seeking questions. Furthermore, the results mostly confirm the analysis presented in Estebas-Vilaplana and Prieto (2010), where confirmation questions, illustrated by the tag ieh?, are indeed realized with a rising contour ( $\mathrm{L}^{*} \mathrm{H} \%$ ). Nevertheless, our results do confirm those of Elordieta, Masa, and Romera (2020) in that they also show more variation, i.e. they suggest a more complicated picture than EstebasVilaplana and Prieto (2010)'s overview on final contours.

Turning now to the factors that might explain this pattern, first a remark is due. Although it is commonly assumed that units of intonation carry (pragmatic) meaning (Ladd, 2008; Prieto, 2015), it is much less clear which units of intonation have an independent meaning (individual tones or whole tunes or contours), and how concrete their contribution to the meaning of a given utterance is (notions like openness, uncertainty, finality or pedagogical flavour are rather vague and not easy to define), see also Büring 2016). According to a holistic approach, whole tunes or contours (combinations of pitch accents and boundary tones) can have a meaning, even though the mapping between intonational contours and pragmatic meanings is by no means univocal (Hualde and Prieto, 2015) and the differences between those contours are rarely categorical, rather matter of a degree (Escandell-Vidal and Prieto, 2020). In this sense, it is of no surprise that clause types or speech act types cannot be univocally identified with specific contours, especially, because the tag is monosyllabic.

Considering RQ A), Hypothesis 1 and 2 are borne out: as can be seen in Figure 8, utterances containing declarative host clauses involve smaller tonal excursions than those containing imperative host clauses, whereas those involving exclamatives involve wider pitch range than both directives and imperatives. There are, however, two sentences that show exceptional behaviour. One of them has a declarative base clause (Es como el $H T M L$, ¿no? 'It is like HTML, isn't it?'), but patterns with exclamatives in that it displays larger pitch excursions. Note that it conveys a factual statement, whereas the other declarative examples express subjective statements. We suppose that this exceptional pattern has pragmatic reasons. The speaker shows real uncertainty and cannot fully commit to the propositional content of the sentence without confirmation from the addressee, thus the question is not simply a meta-question on the attributability of the speech act. The other case, that of the interrogative clause conveying a rhetorical question is different. Although the speech act type is arguably also assertive (Asher and Reese, 2007), the base clause is interrogative, which could explain the wider pitch range and the larger number of rising contours over the tag.

As regards RQ B), Hypothesis 3 is only partially borne out: the commissive speech act is, as expected, associated almost exclusively with sharp rising tones, whereas assertive speech acts display less rising, and more level contours. Directives, especially those conveying a weak command (advice) are in-between. However, from a pragmatic perspective, the high number of rising contours in the case of expressives was not expected, since expressives (more precisely, exclamatives), just like assertives, are supposed to be easily attributable to the addressee. As we have seen, the result can manifest the influence of the clause type of the base clause. The high number of sharp rises in the case of the already mentioned factual statement also confirms the hypothesis 
that it involves a real confirmation question.

Concerning RQ C), at this point we can only provide a tentative analysis. As explained in sections 3.3 and 3.4, we assume with Kiss (2018) that the tag ino? is responsible for the attribution of the given speech act to the addressee. Complying with Hypothesis 4, we assume that the (predominantly) rising contour over the tag signals the call on the addressee performed, i.e. the speaker calls on the addressee to interpret his or her move as a (meta-)question on the attribution of the given speech act ('You would say the same, right?'). However, the gradual differences in the contour correspond, to the speaker's confidence in the attributability of the speech act (assertives are generally more easily attributable than directives and commissives), which is, on the other hand, overridden by the intonational properties of the clause type of the base clause (wider pitch excursions in the case of exclamatives), which is then carried over to the tag as well.

\section{Conclusion}

In this paper we have looked at the prosodic realization of Spanish ¿no?-tags according the clause type of the base clause it is added to, and to the speech act it modifies. Although the contour over the tag is, in the majority of the cases rising, there are level and falling tags as well. The distribution of these contours might have multifaceted reasons: idiolectal differences, the characteristics of the Extremaduran dialect that shows more variability than the Central Castilian one, but at the same time, grammatical and pragmatic factors are also supposed to play a role. Concerning the grammatical factors, we concluded that the clause type of the base clause influences the prosodic realization of the tag (larger pitch span and more rising contours by exclamatives and interrogatives than in the case of imperatives and declaratives). As regards the pragmatic side, we assumed (with Kiss (ibid.)) that the tag realizes the attribution of the given speech act to the addressee, and posited that the contour over the tag also reflects the expected attributability of the given speech act (assertives are more readily attributable than directives, rhetorical questions or commissives) However, assertive speech acts conveying factual statements show a different behaviour, in that they are most often realized with a rising contour, unlike other assertives. We explained this by pragmatic factors in that they realize real confirmational questions. Furthermore, we also made an attempt to account for the dominance of rising contours in claiming that it signals the call on the addressee to interpret the discourse move as a meta-question on the attribution itself.

\section{Acknowledgments}

I would like to thank the two anonymous reviewers for their useful insights and comments on several issues discussed in the present paper. Needless to say, only I am responsible for any remaining errors and shortcomings. Please note that the author was affiliated to the University of Mainz during the time the research presented in the paper was conducted, and it is part of her Habilitation thesis. The empirical study in Cáceres was financially supported by the Romance Seminar of the University of Mainz. 


\section{References}

Asher, Nicholas \& Brian Reese. 2007. Intonation and discourse: Biased questions. In Ishihara, S., S. Jannedy, and A. Schwarz (eds.), Interdisciplinary studies on information structure $\quad 8$ : 1-38. https://doi.org/10.1093/acprof:oso/9780199570959.003.0007

Beyssade, Claire \& Jean-Marie Marandin. 2006. The speech act assignment problem revisited: Disentangling speaker's commitment from speaker's call on addressee. In O. Bonami and P. Cabredo Hofherr (eds.), Empirical issues in syntax and semantics 6: 37-68.

Büring, Daniel. 2016. Intonation and meaning. Oxford: Oxford University Press.

Butt, John \& Carmen Benjamin. 2013. A new reference grammar of modern Spanish.London/New York: Routledge.

Cresti, Emanuela \& Massimo Moneglia. 2005. C-ORAL-ROM: integrated reference corpora for spoken romance languages. Amsterdam: Benjamins. https://doi.org/10.1007/s10590-007-9025-y

Dehé, Nicole \& Bettina Braun. 2013. The prosody of question tags in English. In English Language and Linguistics 17: 129-156. https://doi.org/10.1017/s1360674312000342

Elordieta, Gorka, Masa, Lucía \& Magdalena Romera. 2020. Aproximación entonativa al español hablado en Cáceres. In Estudios de fonética experimental 29: 215-239.

Escandell-Vidal, Victoria. 1999. Los enunciados interrogativos: Aspectos semánticos y pragmáticos. In I. Bosque and V. Demonte (eds.), Gramática Descriptiva de la Lengua Española. Vol. 3. Madrid: Espasa Calpe: 3929-3992. https://doi.org/10.4312/linguistica.41.1.176-178

Escandell-Vidal, Victoria. 2017. Intonation and evidentiality in Spanish polar interrogatives. In Language and Speech 60.2: 224-241. https://doi.org/10.1177/0023830917698178

Escandell-Vidal, Victoria \& Pilar Prieto. 2020. Pragmatics and prosody in research on Spanish. In J. C. Félix-Brasdefer and D. A. Koike (eds.), The Routledge Handbook of Spanish Pragmatics: Foundations and interfaces. London/New York: Routledge. https://doi.org/10.4324/9780429455643-11

Estebas Vilaplana, Eva. 2009. Cuatro niveles de altura tonal en la frontera de frase en español peninsular. In Onomázein. 20.2: 11-32.

Estebas-Vilaplana, Eva \& Pilar Prieto. 2010. Castilian Spanish intonation. In P. Prieto and P. Roseano (eds.), Transcription of intonation of the Spanish language, LINCOM Studies in Phonetics 06: 17-48. https://doi.org/10.1075/sic.10.2.08fac 
Farkas, Donka F \& Kim B. Bruce. 2010. On reacting to assertions and polar questions. In: Journal of semantics 27.1: 81-118.

Farkas, Donka F \& Roelofsen, Floris. 2017. Division of labor in the interpretation of declaratives and interrogatives. In Journal of Semantics 34.2: 237-289. https://doi.org/10.1093/jos/ffw012

García Vizcaíno, María José. 2005. El uso de los apéndices modalizadores ¿no? y ¿eh? en español peninsular. In Selected Proceedings of the Second Workshop on Spanish Sociolinguistics. Cascadilla Proceedings Project. Somerville, MA: Cascadilla Proceedings Project: 89-101.

Ginzburg, Jonathan. 1996. Dynamics and the semantics of dialogue. In J. Seligman and D. Westertahl (eds.), Logic, language and computation 1. CSLI Lecture Notes, Stanford: CSLI Publications.

Ginzburg, Jonathan and Sag, Ivan. 2000. Interrogative investigations. Stanford: CSLI publications.

Hualde, José Ignacio \& Pilar Prieto. 2015. Intonational variation in Spanish: European and American varieties. In S. Frota and P. Prieto (eds.), Intonation in romance, Oxford, OUP: $350-391$.

https://doi.org/10.1093/acprof:oso/9780199685332.003.0010

Kiss, Angelika. 2018. Attributing illocutionary acts in Spanish by the tag question no?, ms.

Ladd, D Robert. 2008. Intonational phonology. Cambridge University Press.

Malamud, Sophia A \& Tamina Stephenson. 2015. Three ways to avoid commitments: Declarative force modifiers in the conversational scoreboard. In Journal of Semantics, 32.2: 275-311. https://doi.org/10.1093/jos/ffu002

Ortega Olivares, Jenaro. 1985. Apéndices modalizadores en español: Los 'comprobativos'. In Estudios románicos dedicados al profesor Andrés Soria Ortega 1, Granada: Secretariado de Publicaciones de la Universidad de Granada: 239- 255.

Osa, Adriana. 2017. Negotiation of discourse moves: right periphery tags. In SEMDIAL 2017 SaarDial, 97-103. https://doi.org/10.21437/semdial.2017-8

Pierrehumbert, Janet \& Julia B. Hirschberg. 1990. The meaning of intonational contours in the interpretation of discourse. In P. R. Cohen, J. Morgan and M.E. Pollack (eds.), Intentions in communication, Cambridge, MA: MIT Press.

Portes, Cristel, Beyssade, Claire, Michelas, Amandine and Marandin, Jean-Marie. 2014. The dialogical dimension of intonational meaning: Evidence from French. In: Journal of Pragmatics 74: 15-29. https://doi.org/10.1016/j.pragma.2014.08.013

Portner, Paul. 2018. Commitment to priorities. In New Work on Speech Acts. Oxford: 
Oxford University Press.

Prieto, Pilar. 2015. Intonational meaning. In Wiley Interdisciplinary Reviews: Cognitive Science 6.4: 371-381. https://doi.org/10.1002/wcs.1352

Prieto, Pilar \& Roseano, Paolo. 2010. Transcription of intonation of the Spanish language. München: Lincom Europa.

Prieto, Pilar \& Paolo Roseano. 2021. The encoding of epistemic operations in two Romance languages: The in- terplay between intonation and discourse markers. In Journal of Pragmatics 172: 146-163. https://doi.org/10.1016/j.pragma.2020.11.008

Stalnaker, Robert C. 1978. Assertion. In P. Cole (ed.), Pragmatics. vol. 9 of Syntax and Semantics. New York: Academic Press: $315-332$. 